\title{
SiM
}

\section{Women as Partners in Pastoral Production in Afghanistan}

\author{
By Catherine A. Schloeder, Michael J. Jacobs, M. Dawood Sherzad, Zohal Maqsoodi, \\ and Hadia Banwal
}

\section{On the Ground}

- The Kuchi are pastoralists who raise sheep and goats on the rangelands.

- Kuchi women are equal partners in the success of pastoral production, despite facing unique risks.

- Kuchi women are unskilled, illiterate, and underserved, and remain constrained by cultural beliefs. They are eager, however, to improve the welfare of themselves and their community when given appropriate opportunities.

- Women with training demonstrate they are more than capable of finding effective and sustainable solutions for female-related problems.

- Building the capacity of motivated women and supporting their efforts outside the home to resolve conflicts themselves are keys to success.

Keywords: PEACE Project, women's empowerment, pastoral development, risk management, conflict management.

\section{Las mujeres como socias en la producción pastoral de Afganistán}

\section{Perspectiva desde el campo:}

- Las kuchis son pastoras que crian borregos y cabras en los pastizales y tierras silvestres.

- Las mujeres kuchis son socias igualitarias en el éxito de la producción pastoril, a pesar de que se enfrentan a riesgos singulares.

- Las mujeres kuchis carecen de capacitación, son analfabetas, marginadas y siguen estando limitadas por las creencias culturales. Sin embargo, están ansiosas por mejorar el bienestar de ellas mismas y su comunidad cuando se les brindan las oportunidades adecuadas.

- Una vez que reciben capacitación, las mujeres demuestran que son más que capaces de encontrar soluciones efectivas y sostenibles para los problemas relacionados con el sector femenino.

- La construcción de la capacidad de las mujeres motivadas y el apoyo de sus esfuerzos fuera de casa para resolver los conflictos por sí mismas son las claves para el éxito.

\footnotetext{
I $\mathrm{n}$ Afghanistan, 5\% of the rural population is engaged almost exclusively in extensive livestock production (henceforth termed pastoral production) yet there have been few gender studies related to this livelihood, particularly with respect to the role of women or the risks they face as partners. Pastoralists in Afghanistan are referred to as Kuchi - a term meaning to move in Persian, today. Afghanistan's Kuchi raise sheep and goats for multiple purposes including dairy, wool, hair, meat, and hide production (Fig. 1). They also play an integral role in Afghanistan's economy by providing more than $75 \%$ of the live animals brought to mar-
}

ket each year. ${ }^{1}$ Historically, Afghanistan's farmers and pastoralists have had many positive relationships involving the exchange of goods and services. ${ }^{2}$ Decades of conflict, periodic droughts, and a growing need for agricultural land, however, have had a negative impact on these relations. Pastoral production, as a consequence, is under threat. ${ }^{3}$ Today, over half of Afghanistan's total Kuchi population is settled, with many living in poor living conditions increasing the likelihood of starvation. More importantly, they represent $70 \%$ of the country's Internally Displaced Population (IDP) and the norm for these IDPs is poverty and food insecurity. ${ }^{4,5} \mathrm{Ad}-$ 


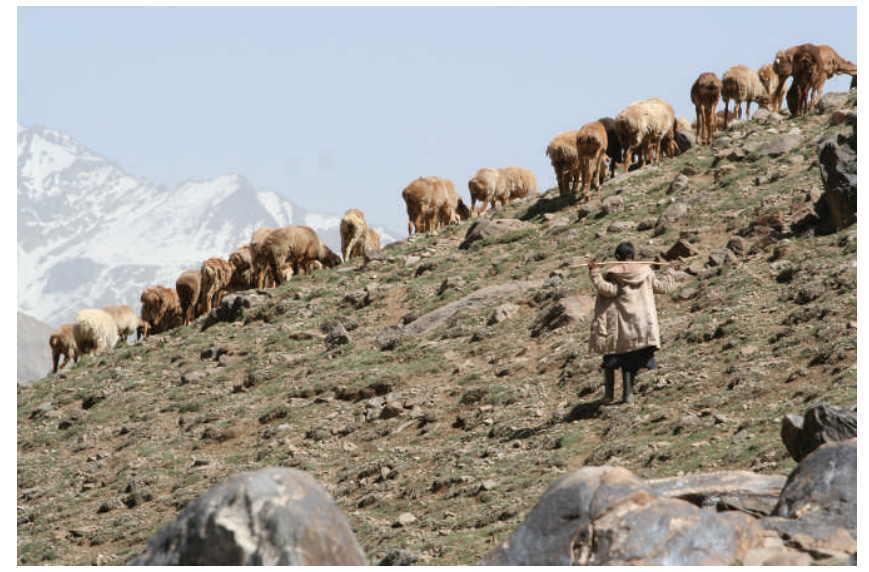

Figure 1. Boy herding livestock in Panjshir Mountains, Afghanistan. Photo courtesy of M. J. Jacobs.

ditionally, those still herding face a myriad of risks in their pursuit of this livelihood. ${ }^{3,6}$

\section{Kuchi Women's Issues}

Informal discussions with Kuchi women indicate that they are integral to production and that their role as partners in this livelihood is not dissimilar to the role of female pastoral producers elsewhere in the world. ${ }^{7}$ Kuchi women are responsible for overseeing the birthing of lambs and kids, caring of newborns and young, fiber collection and processing, milking, processing of dairy products, weaving, fetching water, and maintaining the family dwelling. In contrast, Kuchi men are responsible for all decisions related to seasonal migration, herding, shearing, slaughtering, veterinary needs, livestock marketing, and forage supplies (Fig. 2).

Cultural norms decree that ownership of the herd is vested with the male head of the family and that he is responsible for financially supporting all family members contributing to the success of this livelihood regardless of their role or gender. The head also makes all household decisions related to education, health, income distribution, and spending. There are some exceptions to male ownership of livestock, but they are rare: when a parent gives their daughter livestock as a wedding gift and when animals are transferred to the wife upon the death of her spouse. Transferring property to a wife is generally only done for the purpose of safe-keeping, however, with the actual intent being that she is keeping the herd in trust until the eldest son reaches an age where he can assume the responsibility. In those rare instances of female ownership, income generated from any sales is generally kept by the woman and used at her discretion.

There are gender differences when it comes to literacy and employment as well. In general, illiteracy is high among men 30 years or older and all women. This has changed somewhat in the last decade with more men attending school and graduating, particularly among settled groups and those with permanent residences. There has been an increase in the number of females attending school as well, but in very limited in-

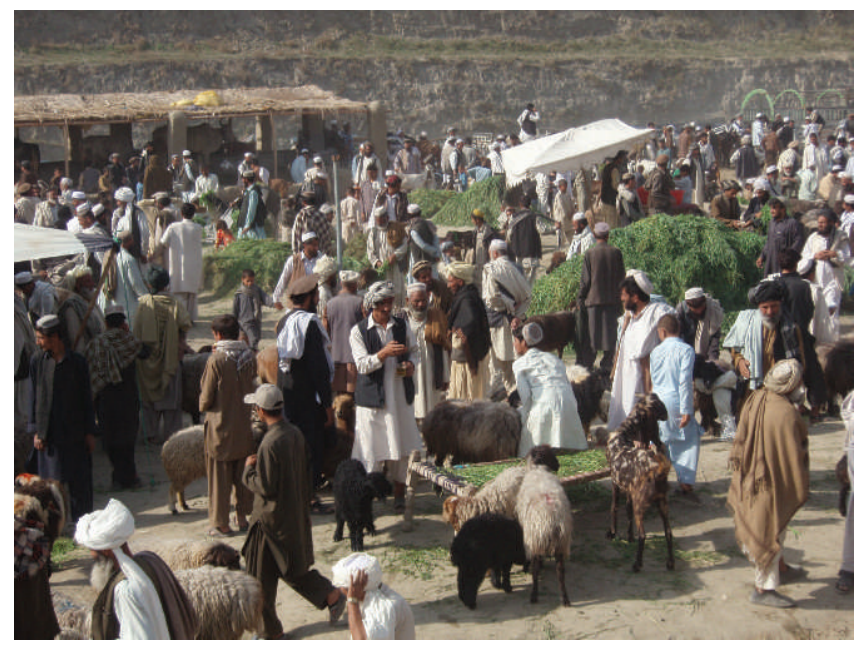

Figure 2. Buyers and sellers on market day in Jalalabad Livestock Market, Afghanistan. Photo courtesy of M. D. Sherzad.

stances. Unlike males, however, females are required to drop out of school if they marry before completing their education. Employment in nonagricultural vocations is also very rare in Afghanistan. Kuchi women, particularly of Pashtun ethnicity, are virtually excluded from engaging in remunerative activities outside of the home. The reason is that cultural norms dictate that it is the man who is responsible for working and providing for the family, and the woman who is responsible for maintaining the household.

\section{Livelihood Challenges: Risks and Conflicts}

There are many risks to pastoral production in the country today, including insecurity and conflict, land conversions and appropriations, limited access to health care and education, and poor economic diversification, to name a few. ${ }^{3,6}$ The degree and extent to which Kuchi women are vulnerable to these risks is equal to or greater than that for men, depending on the risk and location of the family when exposed to the risk. For example:

- If the family has to find an alternative migration route, in the event of a conflict, Kuchi women risk abduction and rape as a consequence of the family not having previously ensured safe passage along the new route. Criminals and corrupt and powerful commanders and warlords are often the culprits in these situations.

- There are few female healthcare providers in Afghanistan, particularly in rural environments. The result is that a woman with a female health issue will generally have to forego treatment unless her family believes her issue sufficiently serious to warrant hiring a vehicle to transport her to a clinic employing a female physician.

The Kuchi also experience conflict among their own over such issues as broken marriage contracts, domestic relations, grazing rights, elopements, religion, economics, education, 
independence, and property rights, to name a few. Conflicts are also quite frequent within the family, which is not surprising given that it is common for 30 or more family members to reside in the same compound. These range from conflicts between a father and son, two or more brothers, sisters-inlaw, a husband and wife, a wife and her husband's family, cowives, and cousins.

\section{Managing for Risk and Conflict}

Pastoral production is a livelihood historically fraught with risk. As a consequence, preventing, coping, and mitigating risks have been the rule rather than the exception. The only difference over time is the nature of the risks that must be managed. In the last decade, the pastoralists in Afghanistan have made efforts to manage their risks in several new ways: assuming a unified national identity as Kuchi to describe all people whose livelihood involves extensive livestock production; securing 13 seats in Parliament, three of which are filled by women; and having language added to the Constitution aimed at providing the Kuchi with housing and a secure future. They have also further cemented their national identity through the formation of the Independent General Directorate of Kuchi (IGDK). The IGDK is a government institution with the mandate to improve food security, access to government services, land tenure, and grazing rights for all Kuchi. Currently, the IGDK has 31 Provincial Directors, all of whom are male, whose responsibility is to determine what the needs of their constituents are and to address these needs where possible.

In 2006, the IGDK collaborated with the Afghanistan Pastoral Engagement, Adaptation and Capacity Enhancement Project (PEACE), in an effort to further improve their capacity to support their constituents. Funding was provided to IGDK Directors to support their monthly shuras (or meeting groups). PEACE also provided training in report preparation, information transfer, and collected metrics on $\mathrm{Ku}^{-}$ chi family sizes, distribution, conflict and social issues, and herd sizes, on behalf of the IGDK. In collaboration with the Sanayee Development Organization, 31 IGDK Provincial Directors (PD) and 485 district and clan-level Kuchi leaders received training as well in peace-building and conflict resolution techniques. Funding for those leaders active in mediating conflicts was also provided so they could provide their own peace-building and conflict resolution training workshops. These efforts also led to the development of a Peace Ambassador (PA) program, involving 75 Kuchi and non-Kuchi leaders, for the purpose of supporting national and provincial-level efforts to mediate specific types of armed conflicts between Kuchi and non-Kuchi. ${ }^{8}$ Of note, by October 2012, the PAs completing this training had successfully mediated over 3,400 social and land-use conflicts, and today they continue without further oversight or support. ${ }^{8}$

In an effort to ensure sustainability, 69 next-generation Kuchi men also received training in peace-building and conflict resolution techniques. At the request of some IGDK
Provincial Directors, six Kuchi women also participated in this effort. Today, reports from several of the young men indicated that they were actively working with their fathers to mediate conflicts while others reported working to mediate conflicts among their peers in addition to forming men-only working groups to identify and mediate conflicts in their communities.

An informal survey of what five of the women trainees have accomplished since their training has also revealed that they are frequently using their skills to mediate a variety of conflicts. Specifically, all responded that it was either common or their job to mediate conflicts among their family and that it was common or their job to mediate conflicts involving women in their village. Solving conflicts among female strangers, however, rarely or never occurred with the exception of one woman trainee who did report traveling periodically to neighboring villages and provinces to mediate problems involving women. This woman commented that she only did so in collaboration with a male leader, also trained in conflict mediation, at the specific request of the leader, village representative, or family.

The types of conflicts these women have mediated to date include conflicts between sisters-in-law, mother-in-law and daughter-in-law, husband and wife, two families, and engaged couples. Two of the five trainees also responded having experience with domestic violence issues, with one following up with the comment that it was a personal priority to "prevent this issue from occurring." In contrast, all women responded that they rarely or never mediated issues related to money, work, co-wives, jealousy, health, or religious needs. All women also responded that their families either always or sometimes supported their work and that support was unanimous when it involved issues within the family, among relatives, or women in the village. They also responded that most women in the village supported their work. In contrast, three responded that there was some resistance to their efforts by men and that the resistance came from family members or leaders who did not believe females should be working outside the home. Four of the five women also responded that they never mediated a conflict if it required travel beyond their village.

All five women reported that they have also taken the initiative, since their training, of forming a women's group in their village to discuss and attempt to resolve issues related to education, health, property rights, and finances. Of these, one has also formed a provincial-scale women-only shura in an effort to solving women's issues on a much larger scale. The woman who has done this is the same woman who is allowed to travel to mediate female-related conflicts. This woman also responded that no men have a problem with her working. When asked further about her ability to travel freely, she claimed that her ability to do so was because her family believed in her work and because she had very strong tribal affiliations. The latter claim suggests that she comes from an economically or politically powerful family and as a result, 
men are unlikely to openly question her family's decisions. That said, "strong" families are often looked to for help in their communities.

\section{Moving Forward}

Kuchi women have few property rights; are untrained, illiterate, and underserved; and remain shielded in their own homes due to cultural beliefs. What emerges from working with them, however, is that they are eager to improve the welfare of themselves and their communities despite these challenges. Women who have had training have also demonstrated that they are more than capable of identifying and finding effective and sustainable solutions for female-related problems. There is still much resistance to women working outside the home, however, and this will not change until there is more support from men, their families, and community to work outside their homes. Men who are not intimidated by working with women will ultimately make this possible, by example.

There are few rangeland programs that serve to empower women pastoralists in developing countries and none in Afghanistan at this time. One reason is that it takes time to gain the trust and respect of Kuchi men, and to demonstrate to them the benefits of various training opportunities regardless of gender. For example, it took four years of trust-building with provincial IGDK Directors, and many positive results, before they were open to the offer of training for women. Mentoring throughout the trust-building process was also critical. Challenging environments such as Afghanistan can be overwhelming, even to nationals, and lead to feelings of frustration. Encouragement and patience throughout helped maintain participation, sustain motivation, and build trust.

Another reason that women pastoralists are often overlooked is that most, if not all, programs are geared to improving production or range management from a technical perspective. Technical programs, in environments such as this, are guaranteed to fail when they ignore the cultural and social challenges and issues, and the degree to which the people on the ground control a situation. Programs should instead be geared towards investing in those individuals and communities actually dependent on pastoralism, so that they can acquire skills to increase their ability to understand, resolve, and improve the situation themselves.

When it comes to future programs targeting Kuchi women, it should be kept in mind that following local cultural and social rules is critical to success. For example, local leaders are the ones who rule and set precedents in their communities. For this reason, it is essential that the IGDK Provincial Directors and community leaders be participants in the selection of women from their area for training. Unquestionably, the first to be nominated will be near or distant relatives, but this should be viewed positively because there is a greater probability that a leader's relative will be allowed to work outside of the home upon completion of her training. Another cultural rule of import is the need for a male escort for those women traveling to and participating in any training program. The need for a male escort means additional costs, but this should be viewed as an opportunity to gain support from men in that the escort will certainly learn while observing the training and consequently be more likely to endorse the need for the woman to get out and work when she returns home. Additional funding will also be needed if there are plans to support a female's efforts outside of the home or women's gatherings involving multiple communities. These include the cost of transportation, male escorts, meals, and possibly the provision of an acceptable venue.

Otherwise, training programs for women are similar to those for men in that they require:

- Careful and thoughtful selection of institutional partners,

- An effective monitoring and evaluating program,

- Adherence to an accountability protocol,

- Only working with people that the community trusts,

- Establishing parameters at the start that clearly state the purpose and intent of the program,

- Adoption of strict protocols regarding acceptable participation and behavior, and

- Participants having a voice in finding and choosing solutions to a problem.

Success also hinges on implementers remembering that they may be the ones who are creating and supporting a process, but ultimately it is the participants who will make it work (or not). The consequence of this approach, as opposed to one where all terms are dictated to the participants, will ultimately be an improved livelihood, improved lives, and a culture of empowered people.

\section{Acknowledgments}

We are indebted to many Afghan women and men for their bravery and commitment to making a change and difference in Afghanistan. Without their support and partnership, this publication would not have been possible. PEACE was implemented by Texas A\&M University. Our implementing partners included University of California, Davis; Independent General Directorate of Kuchi; President Karzai's Advisor on Tribal Affairs; Sanayee Development Organization; and Mercy Corps. Travel support was provided to Schloeder by the SRM Board of Directors and SRM International Affairs Committee to participate in the 2013 symposium "Women as Change Agents on the World's Rangelands" in Oklahoma City. This presentation formed the basis of this article.

\section{References}

1. Schloeder, C. A. And Jacobs, M. 2009. Afghanistan livestock market assessment: report on Afghanistan livestock market dynamics, October 2008-October 2009. Afghanistan PEACE Project. College Station, TX, USA: Texas A\&M University, Department of Ecosystem Science and Management. Techni- 
cal Report. 45 p. Available at: http://cnrit.tamu.edu/peace/pdfs/ PEACE/Livestock Market Synthesis Report J.pdf. Accessed 10 April 2013.

2. Schütte, S. 2012. Pastoralism, power and politics: access to pastures in Northern Afghanistan. In: H. Kreutzmann [ED.]. Pastoral practices in High Asia: advances in Asian human-environmental research. Springer Science and Media, Dordrecht, The Netherlands. p. 53-69.

3. Jacobs, M. J. And C. A. Schloeder. 2012. Extensive livestock production: Afghanistan's Kuchi herders, risks to and strategies for their survival. In: V. Squires [ED.]. Rangeland stewardship in Central Asia: balancing improved livelihoods, biodiversity conservation and land protection. Springer Science and Media, Dordrecht, The Netherlands. p. 109-127.

4. Ministry of Rehabilitation and Rural Development and the Central Statistics Office. 2007. National Risk and Vulnerability Assessment 2005. Available at: http://home. wfp.org/stellent/groups/public/documents/ena/wfp193560.pdf. Accessed 10 April 2013.

5. Ministry of Rehabilitation and Rural Development and Central Statistics Office. 2009. National Risk and Vulnerability Assessment 2007/8: A Profile of Afghanistan. Cologne, Germany: ICON-Institute GmbH \& Co KG Consulting Gruppe.

6. Desta, S. 2009. Risk Management Strategy for Kuchi Herders in Afghanistan. Report prepared for Afghanistan PEACE Project. College Station, TX, USA: Texas A\&M University, Department of Ecosystem Science and Management. Technical Report. 21 p. Available at: http://cnrit.tamu.edu/peace/pdfs/
PEACE\%20Risk\%20Assessment\%20Report\%20Jan\%202009. pdf. Accessed 10 April 2013.

7. FAO. 2011. The State of Food and Agriculture 2010-2011. Women in agriculture. Closing the gender gap for development. Available at: http://www.fao.org/docrep/013/i2050e/i2050e00. htm. Accessed 10 April 2013.

8. Jaсовs, M. J. 2013. Conflict resolution handbook: lessons and recommendations. Afghanistan PEACE Project. College Station, TX, USA: Texas A\&M University, Department of Ecosystem Science and Management. Technical Report. 25 p. Available at: http://cnrit.tamu.edu/peace/pdfs/PEACE_Handbook_web.pdf. Accessed 10 April 2013.

Authors are Senior Member of Oikos Services, LLC, Fortine, MT 59918, USA, caschloeder@gmail.com (Schloeder); Research Scientist at Texas AE'M University, College Station, TX 77845, USA (Jacobs); Program Manager (Sherzad) and Training/Supporting Officers at Mercy Corps, Kabul, Afghanistan (Maqsoodi and Banwal). This publication was made possible through support provided to the Pastoral Engagement Adaptation and Capacity Enhancement (PEACE) project by the Office of Agriculture, US Agency for International Development (USAID) under the terms of Cooperative Agreement 306-A-00-06-00521-00 to the University of California, Davis.

Rangelands 35(6):58-62

doi: 10.2111/RANGELANDS-D-13-00030.1

(C) 2013 The Society for Range Management 